\title{
Oculo-palato-cerebral syndrome
}

INSERM

\section{Source}

INSERM. (1999). Orphanet: an online rare disease and orphan drug data base. Oculopalato-cerebralsyndrome. ORPHA:2714

Oculopalatocerebral syndrome is characterised by the association of four anomalies: intellectual deficit, microcephaly, palate anomalies and ocular abnormalities. 